\title{
Mantias - an eye doctor of the emperor Tiberius
}

\author{
Peter ROTHENHÖFER*
}

Augustus repeatedly struggled with serious illnesses during his lifetime. ${ }^{1}$ Just the opposite applied to his successor, Tiberius. ${ }^{2}$ Suetonius emphasizes that Tiberius enjoyed a good state of health, „without interruption, almost during the whole period of his rule", and that he lived since he was 30 sine adiumento consiliove medicorum, without any medical assistance or advice. ${ }^{3}$ Albert Esser in his book on the healthiness and illnesses of the emperors of the Julio-Claudian dynasty made a similar statement: „Die ausgezeichnete körperliche Verfassung lässt von vorneherein erwarten, dass Tiberius von jeher und fast ständig einer guten Gesundheit sich erfreute. In der Tat war es so. ${ }^{“ 4}$

However, a phenomenon concerning his eyes is reported by various ancient authors: Suetonius mentions in chapter 68 of the Life of Tiberius that he had unusually large eyes, cum praegrandibus oculis, and a wonderful visual capacity in both the night-time and the dark, though only for a short time. ${ }^{5}$ But this doesn't suggest an eye disease. Concerning his eyes we find a further remark in Dio (57.2.4): In $\mathrm{AD} 14$, when he was offered the rule after the death of Augustus, Tiberius played the role of a hesitator and vacillator: „At first he kept saying he would give up the rule entirely on account of his age (he was 56) and of his nearsightedness (for although he saw extremely well in the dark, his sight was very poor in the daytime). "Nearsightedness or myopia is now understood as a prevalent refractive error of the eye, causing eye strain and headaches. Therefore, it seems reasonable to assume that Tiberius suffered from it and that he sought the medical advice and treatment of an eye doctor.

An otherwise unattested Roman eye doctor is presented here who is mentioned on an unpublished funerary inscription. ${ }^{6}$ The short and well-preserved text is found on a rectangular marble slab. Its dimensions are $21.6 \times 12.7 \times 2.5 \mathrm{~cm}$. The inscription consists of four lines, and the letters are well engraved (fig. 1). It reads:

\footnotetext{
* Dr. Peter Rothenhöfer, Kommission für Alte Geschichte und Epigraphik des Deutschen Archäologischen Instituts, Amalienstr. 73b, D-80799 München (pma.rothenhoefer@gmail.com).

${ }^{1}$ See Esser 1958, 37-73, especially the overview given on pp. 59-61. - I am very grateful to David N.-M., who draw my attention to the object.

${ }^{2}$ Esser 1958, 74-103.

${ }^{3}$ Suet. Tib. 68 .

${ }^{4}$ Esser 1958, 83.

${ }^{5}$ Similiar Plin. n. h. 11.37: ferunt Ti. Caesari, nec alii genitorum mortalium, fuisse naturam (ut) expergefactus noctu paulisper haut alio modo quam luce clara contueretur omnia, paulatim tenebris sese obducentibus. See also Sext. Emp. 1.84. - Cf. Esser 1958, 94-98.

${ }^{6}$ No information about the findspot was obtainable, but presumably it is from Rome. The slab was part of the collection of the US tennis star Eleonora Randolph Sears (1881-1968), Prides Crossing, Massachusetts.
} 


\author{
Mantias \\ $\operatorname{Ti}($ berii) $\bullet$ Caesaris $\bullet$ Aug(usti) \\ medicus • ocular(ius) \\ $\operatorname{vix}($ it $) \cdot \operatorname{ann}($ os $) \bullet X X V I I$
}

Translation: Mantias, eye doctor of Tiberius Caesar Augustus, lived 27 years.

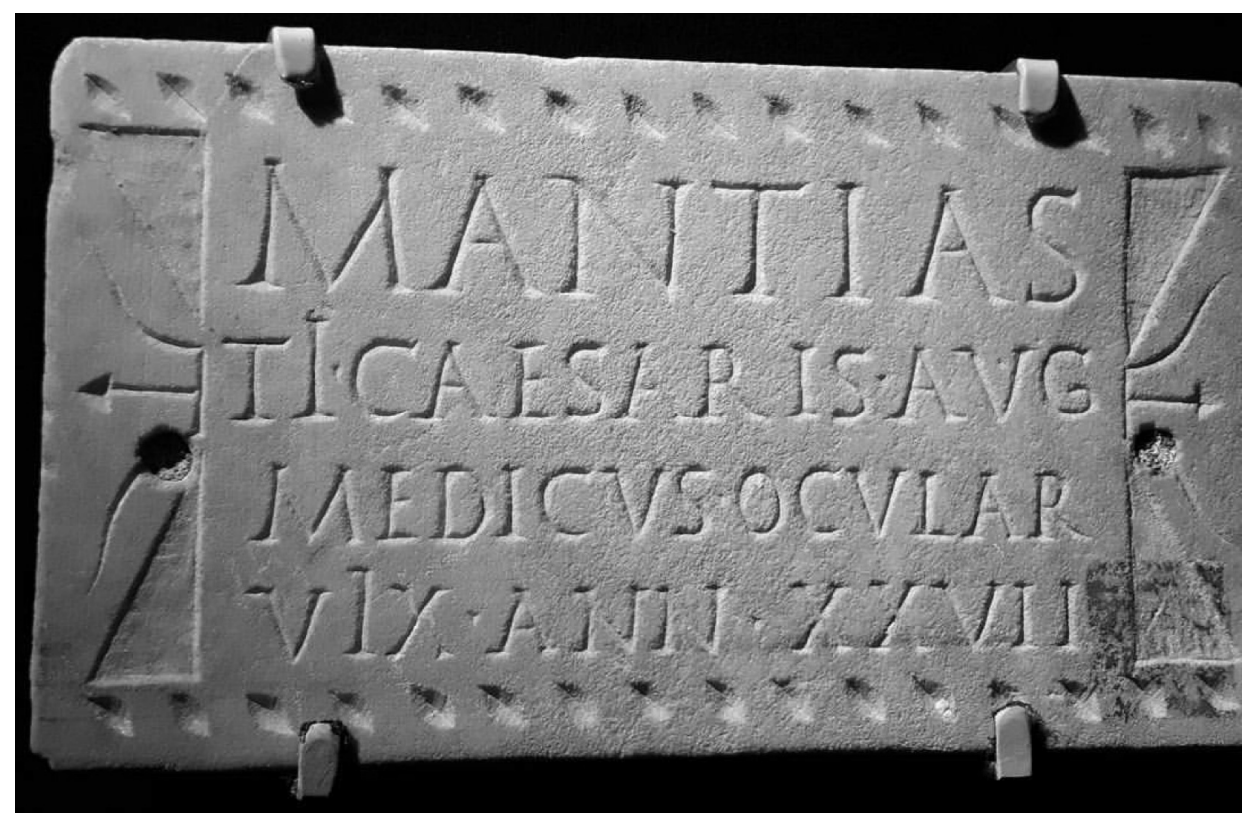

Fig. 1

The first line with the name of the deceased is the biggest one, with a letter height of $2 \mathrm{~cm}$. The letter height in line 2 is $1.3-1.4 \mathrm{~cm}$, with the exception of the I longa of $T I$, which measures $1.7 \mathrm{~cm}$. In line 3 and 4 it is $1.2 \mathrm{~cm}$, the I in VIX in line 4 has $1.5 \mathrm{~cm}$ high. The inscription is written in Capitalis. A line of stylized leaves frames the inscription above and below. The central field is designed as tabula ansata with handles to the left and right of the text. Two mounting holes are visible, each near the transition from the handles to the panel so that the slab could be fixed with nails to the loculus. Presumably the letters were colored in red, but no traces of it have survived.

Mantias was an eye doctor within the familia Caesaris during the reign of Tiberius (AD 14-37). ${ }^{7}$ Presumably he was of Greek origin, like other physicians in $\mathrm{Rome}^{8}$, as the name is attested mainly in mainland Greece. ${ }^{9}$ This inscription offers the first attestation of this Greek name in Rome. ${ }^{10}$

It may be no coincidence that this physician bears the name Mantias. There is a famous Hellenistic physician and pharmacologist with this name, who lived in the second half of the second century

${ }^{7}$ For eye doctors and eye medicine in ancient Rome see Jackson 1996. Cf. Rémy 2010, 50. See also Voinot 1999. Nutton 1972. - For servi medici within the familia Caesaris see Kudlien 1986, 102-104.

${ }^{8}$ Cf. Korpela 1987, 53.

${ }^{9}$ LGPN I (1987) p. 297; LGPN II (1994) p. 297; LGPN IIIA (1997) p. 287; LGPN IIIB (2000) p. 269; LGPN VA (2010) p. 279.

${ }^{10}$ Not mentioned in Solin 1996. 
BC. ${ }^{11}$ On folio $2 \mathrm{v}$ of the Vienna Dioscurides-codex, dated to AD 512, he is depicted as a participant in an imaginary round of discussions (fig. 2). He is sitting there amongst seven famous ancient physicians, of which two, the centaur Cheiron and Machaon, son of the god of medicine Asclepius, are mythological figures; the others, Pamphilus of Alexandria, Xenocrates of Aphrodisias, Sextius Niger, Heracleides of Tarentum, and Mantias (lower right), are known as authors of basic Greek writings on medicine and pharmaceuticals. Thus, there is a reason to assume that the name Mantias was deliberately given to the deceased, which implies that already his parents had been doctors who had been aware of this famous physician.

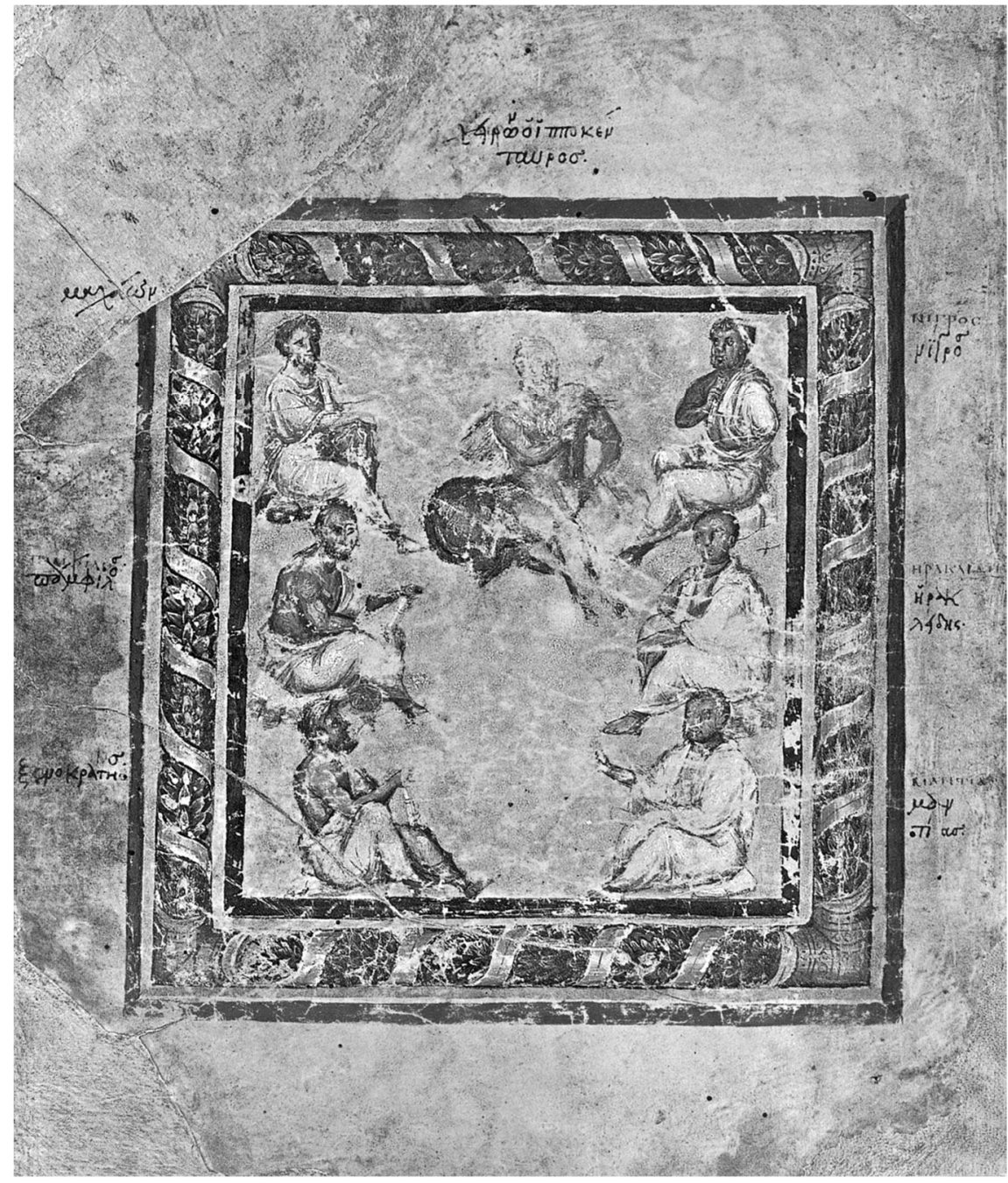

Fig. 2) „The seven physicians“. Vienna, Österreichische Nationalbibliothek, Cod. Med. gr. 1, folio $2 v$.

The great importance of this text is based on the fact that Mantias is referred to as the emperor Tiberius's personal eye doctor: Ti(berii) Caesaris medicus ocular(ius) expresses a personal connection to the emperor Tiberius. Comparable are, for instance, the funeral inscriptions of Ti. Claudius Melito, Germanici medicus ${ }^{12}$, or of Hyginus, Liviae medicus ${ }^{13}$, and of Tyrannus, who also was Liviae

\footnotetext{
${ }^{11}$ RE XIV,1 (Stuttgart 1928) 1257 s.v. Mantias 4; DNP 7 (Stuttgart 1999) 830-831 s.v. Mantias 2.

${ }^{12}$ AE 1941, 64. See Kolb - Fugmann 2008, 165-167 no. 43 with fig.

${ }^{13}$ CIL VI 8903 = Gummerus 1932 no. 51.
} 
medicus $^{14}$. Of a later date is the inscription of L. Arruntius Sempronianus Asclepiades, imp(eratoris) Domitiani medicus ${ }^{15}$. There is no need to stress that the personal physician of an emperor held an exceptional position of trust, as can be seen in the case of Tiberius' Leibarzt Charides, medicus arte insignis, who had, according to Tacitus (ann. 6.50), more the role of an adviser. ${ }^{16}$

Fortunately, another eye doctor of Tiberius is known. On a slab found around AD 1600 in Rome the following text was read:

$$
\begin{gathered}
\text { Thyrius (?) Ti(berii) Caesaris } \\
\text { Aug(usti) ser(vus) Celadianus } \\
\text { medicus ocularius } \\
\text { pius parentium suorum } \\
\text { vixit annos XXX } \\
\text { hic situs est in perpet(uum) }
\end{gathered}
$$

The beginning of line 1 is not absolutely clear: various readings (including TIBERIVS, TI. LVRIVS, TI. LIRIVS, TI. LYRIVS, to ILLYRIVS) have been suggested; cf. the commentary on CIL VI 8909 and the additional remarks on p. 3463. Herman Gummerus (1932, 28 no. 57), Vivian Nutton (1972, 19 no. 9), and Heinrich Chantraine (1967, 307 no. 91) preferred to restore Thyrius at the beginning of the text. But the slightly different epigraphic formula - first the statement of being a slave of the Emperor Tiberius and then, after the name, the indication of his profession - must be interpreted as suggesting that he was only one of several eye doctors within the familia Caesaris. Heinrich Chantraine supposed that perhaps the freedman of Augustus' wife Livia, Celadus, had been the former dominus of Thyrius, ${ }^{17}$ which would mean that some time later Thyrius either was sold to, donated to, or most probably inherited by Tiberius.

That the Roman emperors had several physicians within their familia can be deduced from other inscriptions, e. g. CIL VI 8656 of the imperial freedman C. Iulius Eutyxchus, who was medic(us) ex dom(o) Pal(atinarum), or CIL VI 8671 of C. Iulius Euxinus, who was medicus ex hortis Sallustianis.

Velleius Paterculus reports that Tiberius was sympathetic towards soldiers, staff and people who suffered from diseases and ailments, and that he sent - for instance - physicians to the sick ones. ${ }^{18}$ This observation supports our hypothesis that Thyrius probably was one of several eye doctors within Tiberius' household.

Although it is likely that Mantias was closer to Tiberius than Thyrius, he probably never achieved a position like the above mentioned Charides.

\footnotetext{
${ }^{14}$ CIL VI 3985 = Gummerus 1932, no. 13.

${ }^{15}$ CIL VI 8895 = Gummerus 1932, no. 43. See also Korpela 1987, 66-70 on further imperial physicians.

${ }^{16}$ Cf., for instance, Michler 1993 on Antonius Musa, personal physician of Augustus.

${ }^{17}$ Celadus Augustae l(ibertus): CIL XIV 3524. Cf. Chantraine 1967, 307. Weaver 1972, 90.

${ }^{18}$ Vell. 2.114.2. - Cf. Esser 1958, 83-84, who emphasized that „trotz seiner ärztefeindlichen Einstellung ... war Tiberius als oberster Befehlshaber im Felde stets bemüht, seinen Untergebenen in Krankheitsfällen jede irgendwie mögliche ärztliche Hilfe angedeihen zu lassen“.
} 


\section{Bibliography}

Chantraine 1967

Esser 1958

Gummerus 1932

Jackson 1996

Kolb - Fugmann 2008

Korpela 1987

Kudlien 1986

Michler 1993

Nutton 1972

Rémy 2010

Solin 1996

Voinot 1999

Weaver 1972
H. Chantraine, Freigelassene und Sklaven im Dienst der römischen Kaiser. Studien zu ihrer Nomenklatur, Wiesbaden 1967.

A. Esser, Cäsar und die julisch-claudischen Kaiser im biologischärtzlichen Blickfeld, Leiden 1958.

H. Gummerus, Der Ärztestand im römischen Reiche nach den Inschriften. Societas Scientiarum Fennica, Commentationes Humanarum Litterarum 3,6, Helsingfors 1932.

R. P. J. Jackson, Eye Medicine in the Roman Empire, in: ANRW II 37.3, Berlin/New York 1996, 2228-2251.

A. Kolb - J. Fugmann, Tod in Rom. Grabinschriften als Spiegel römischen Lebens, Mainz 2008.

J. Korpela, Das Medizinalpersonal im antiken Rom, Helsinki 1987.

F. Kudlien, Die Stellung des Arztes in der römischen Gesellschaft. Freigeborene Römer, Eingebürgerte, Peregrine, Sklaven, Freigelassene als Ärzte. Forschungen zur antiken Sklaverei Bd. 18, Stuttgart 1986.

M. Michler, Principis medicus: Antonius Musa, in: ANRW II 37.1 Berlin/New York 1993, 757-785.

V. Nutton, Roman Oculists, Epigraphica 34, 1972, 16-29.

B. Rémy, Les médecins dans l'Occident romain (Péninsule Ibérique, Bretagne, Gaules, Germanies). Scripta Antiqua 27, Bordeuax 2010.

H. Solin, Die stadtrömischen Sklavennamen. Ein Namenbuch, vol. I-III, Stuttgart 1996.

J. Voinot, Les cachets à collyres dans le monde romain. Monographies instrumentum 7, Montagnac 1999.

P.R.C. Weaver, Familia Caesaris. A Social Study of the Emperor's Freedmen and Slaves, Cambridge 1972.

\section{Mantias - İmparator Tiberius’un Göz Doktoru}

Özet

Makalede bugüne kadar bilinmeyen Roma Dönemi'ne ait bir mezar yazıtı incelenmektedir. Mezarın sahibi İmparator Tiberius'un göz doktorudur. Tiberius Dönemi esnasında familia Caesaris mensubu ikinci doktordur.

Anahtar Sözcükler: Tiberius, familia Caesaris, göz doktoru, medicus ocularius, imparatorluk kölesi

\section{Mantias - an eye doctor of the emperor Tiberius}

Abstract

A hitherto unkown Roman funerary inscription is presented here. The deceased was Mantias, eye doctor of the Emperor Tiberius. He is the second eye doctor known from the familia Caesaris during the reign of Tiberius.

Keywords: Tiberius, familia Caesaris, eye doctor, medicus ocularius, imperial slave 